\title{
Comparison between desorption isotherm curves of ryegrass (Lolium multiflorum L.) and flax (Linum usitatissimum L.) seeds
}

\section{Comparação entre curvas isotérmicas de dessorção de sementes de azevém (Lolium multiflorum L.) e linhaça (Linum usitatissimum L.)}

\author{
Paulo Cesar Corrêa' (iD, Juliana Soares Zeymer ${ }^{1 *}$ (D), Gabriel Henrique Horta de Oliveira² ${ }^{(D)}$ \\ Marcos Eduardo Viana de Araujo' (D), Camilla Sena da Silva' ${ }^{1}$ (D)
}

\author{
'Universidade Federal de Viçosa/UFV, Departamento de Engenharia Agrícola e Ambiental, Viçosa, MG, Brasil \\ ${ }^{2}$ Instituto Federal do Sudeste de Minas Gerais, Manhuaçu, MG, Brasil \\ ${ }^{*}$ Corresponding author: jujuszeymer@gmail.com \\ Received in March 4, 2020 and approved in May 27, 2020
}

\begin{abstract}
It is necessary to determine the sorption isotherms of seeds to develop adequate systems of storage and drying. The chemical composition of a product affects the sorption process; products with a high oil content adsorb a lower amount of moisture from the environment than products with a high carbohydrate content. Given the importance of the hygroscopicity of different agricultural products, this work aimed to determine, model and evaluate the difference between desorption isotherms of ryegrass and flax seeds grown at different temperature and relative humidity conditions. Ryegrass and flax seeds, which contained initial moisture contents of 10.4 and $8.7 \%$ (db), respectively, were used. The equilibrium moisture content of the seeds was determined using a static-gravimetric method at different temperatures $(10,20,30,40$, and $50 \pm 1{ }^{\circ} \mathrm{C}$ ) and relative humidity values (between 11 and $96 \pm 2 \%$ ), in three replicates. Seven mathematical models were adjusted to the equilibrium moisture content experimental data of the seeds. The Chung Pfost model best fit the experimental data of ryegrass seeds, whereas the Smith model was determined to be the best fit for flax seeds. The equilibrium moisture content of the seeds was found to decrease as the temperature increased when the value of water activity was constant. The desorption isotherms of ryegrass seeds (Type II) and flax seeds (Type III) are different, according to Brunauer's classification, which is caused by the composition (starch and oil content) of each product.
\end{abstract}

Index terms: Equilibrium moisture content; chemical composition; mathematical modeling; Chung Pfost; Smith.

\begin{abstract}
RESUMO
A fim de desenvolver sistemas adequados de armazenamento e secagem, é necessário determinar as isotermas de sorção das sementes. A composição química do produto influencia o processo de sorção; produtos com alto teor de óleo absorvem menor quantidade de umidade do ambiente, quando comparados a produtos com alto teor de carboidratos. Devido à importância de compreender a higroscopicidade de diferentes produtos agrícolas, este trabalho teve como objetivo determinar, modelar e avaliar a diferença entre as isotermas de dessorção de sementes de azevém e linhaça, em diferentes condições de temperatura e umidade relativa. Utilizaram-se sementes de azevém e linhaça com teor de água inicial de 10,4 e 8,7\% (bs), respectivamente. O teor de água de equilíbrio das sementes foi determinado pelo método estático-gravimétrico em diferentes valores de temperatura $\left(10,20,30,40\right.$, e $50 \pm 1^{\circ} \mathrm{C}$ ) e umidade relativa (entre 11 a $96 \pm 2 \%$ ), em três repetições. Sete modelos matemáticos foram ajustados aos dados experimentais do teor de água de equilíbrio das sementes. O modelo Chung Pfost foi o que melhor se ajustou aos dados experimentais das sementes de azevém, enquanto o modelo Smith foi escolhido para as sementes de linhaça. O teor de água de equilíbrio das sementes diminuiu à medida que a temperatura aumentou, para um valor constante de atividade de água. As isotermas de dessorção de sementes de azevém (Tipo II) e de linhaça (Tipo III) são diferentes, de acordo com a classificação de Brunauer, devido à composição dos produtos (teor de amido e óleo).
\end{abstract}

Termos para indexação: Teor de água de equilíbrio; composição química; modelagem matemática; Chung Pfost; Smith.

\section{INTRODUCTION}

Ryegrass (Lolium multiflorum L.) is a forage widely cultivated in southern Brazil. Its high dry matter yield and high plant and seed nutrition value contribute to ryegrass being one of the primary winter forages cultivated
(Skonieski et al., 2011). Culture production success requires seeds of good physical and physiological quality (Finch-Savage; Bassel, 2016; Araujo et al., 2019). Thus, determining how to improve postharvest procedures, such as drying and storage, is of extreme importance in acquiring high quality seeds. 
Flax (Linum usitatissimum L.) is an oleaginous product extensively cultivated worldwide, characterized by higher productivity in cold and humid climate conditions. It is considered to be a double use crop, due to its primary products: fiber retrieved from the plant and the extracted oil from the seeds (Anastasiu et al., 2016). Demand for these products has been increasing considerably over the most recent decade, due to the human health benefits offered. However, production of this culture has decreased over time. One possible contributor to this trend is the seed quality offered to producers retrieves a lower net income in comparison to other products (Zuk et al., 2015).

To develop and obtain adequate storage and drying systems it is necessary to determine the equilibrium relationship between the moisture content of seeds and the relative humidity of the surrounding environment at several temperatures (Corrêa et al., 2015). Knowledge of desorption isotherms is fundamental to improving the drying process, because it provides information to determinate the final point of this process. In addition, most drying models use the difference between the real moisture content and the equilibrium moisture content as a measure of the mass transfer driving force (Temple; Van Boxtel, 1999). Sorption isotherms are used to characterize the moisture state within solids; furthermore, they are useful for predicting the domain of the physical, chemical and microbiological stability of biosystems after drying. Finally, sorption isotherms may be used to determine more adequate storage conditions for products (Monte et al., 2018).

The chemical composition of a product directly affects the sorption process. According to Brooker, Bakker-Arkema and Hall (1992), products with a high oil content adsorb a lower amount of moisture from the environment when compared to products with a high carbohydrate content. Moreover, the cultivar, maturation stage, physical aspects and shape of a product are key factors to acquire the equilibrium moisture content of hygroscopic materials (Goneli et al., 2018). Oh, Lee and Hong (2018) report that the modeling precision of desorption isotherms is linked to the product type and composition. Materials with different amounts of oil and carbohydrates may present different types of desorption isotherms and require different models to describe them.

Ryegrass seeds are rich in starch and sugar, which causes the seeds to essentially be hydrophilic, requiring more energy and time in the desorption process (Marchesan et al., 2015). However, the high content of oil in flax seed can represent approximately $50 \%$ of the seed mass. Thus, flax seeds are hydrophobic, resulting in a faster desorption process, with lower energetic costs (Cloutier et al., 2011). Due to the differences in the chemical composition of biological materials, the determination of sorption isotherms for each product is indispensable (Sormoli; Langrish, 2015).

In an effort to better understand how the hygroscopicity of different agricultural products assures drying and storage success, this work aimed to determine, model and evaluate the difference between the desorption isotherms of ryegrass and flax seeds in different temperature and relative humidity conditions.

\section{MATERIAL AND METHODS}

The study was conducted in the Agricultural Products Physical Properties and Quality Laboratory belonging to the National Storage Training Center (CENTREINAR), located at the Federal University of Viçosa, Viçosa, MG, Brazil.

Ryegrass seeds (Lolium multiflorum L.) and flax seeds (Linum usitatissimum L.), purchased at a local market in the city of Viçosa-MG, Brazil, had initial moisture contents of 10.4 and $8.7 \%$ (dry basis, db), respectively. The staticgravimetric method was used to determine the equilibrium moisture content of the seeds obtained by desorption.

A saturated salt solution was prepared and placed within desiccators to control the relative humidity of the air (11 to $96 \pm 2 \%$ ) (Table 1$)$.

Table 1: Relative humidity of the air related to saturated saline solutions at temperatures of 10,20 , 30,40 , and $50^{\circ} \mathrm{C}$.

\begin{tabular}{cccccc}
\hline Saline & \multicolumn{5}{c}{ Temperature $\left({ }^{\circ} \mathrm{C}\right)$} \\
\cline { 2 - 6 } Solutions & 10 & 20 & 30 & 40 & 50 \\
\hline $\mathrm{LiCl}$ & 0.13 & 0.11 & 0.11 & 0.12 & 0.11 \\
$\mathrm{CaCl}$ & 0.40 & 0.35 & - & - & - \\
$\mathrm{Ca}\left(\mathrm{NO}_{3}\right)_{2}$ & 0.59 & 0.55 & & & \\
$\mathrm{NaCl}$ & 0.76 & 0.76 & 0.76 & 0.75 & 0.75 \\
$\mathrm{KBr}$ & - & 0.84 & - & - & - \\
$\mathrm{K}_{2} \mathrm{SO} 4$ & - & - & - & 0.96 & - \\
$\mathrm{MgCl}$ & - & - & 0.32 & - & - \\
$\mathrm{KNO}_{2}$ & - & - & 0.48 & - & - \\
$\mathrm{KNO}_{3}$ & 0.96 & 0.93 & 0.91 & - & - \\
$\mathrm{MgCl}_{2} \mathrm{x}$ & - & - & - & 0.32 & 0.31 \\
$6 \mathrm{H}_{2} \mathrm{O}$ & & & - & 0.50 & 0.46 \\
$\mathrm{Na}_{2} \mathrm{Cr}_{2} \mathrm{O}_{7}$ & - & - & - &
\end{tabular}

Source: Dhingra and Sinclair (1995). 
Containers holding $30 \mathrm{~g}$ of seeds were placed in triplicate above the salt solutions. Desiccators were stored in Bio-Oxygen Demand (B.O.D.) incubator (model $347 \mathrm{CD} /$ brand Fanem/Carandiru, SP, Brazil) at different temperatures $\left(10,20,30,40\right.$ and $\left.50 \pm 1{ }^{\circ} \mathrm{C}\right)$.

During the desorption process, samples were weighed daily with the aid of a digital analytical scale (model AY220/brand Marte/São Paulo, SP, Brazil), and hygroscopic equilibrium was reached when the mass variation remained invariable or lower than $0.01 \mathrm{~g}$ for three consecutive measurements of weight. After hygroscopic equilibrium was reached, the moisture content of each sample was determined using the gravimetric method, using an oven with forced air circulation at $105 \pm 1{ }^{\circ} \mathrm{C}$ for $24 \mathrm{~h}$ in three repetitions, according to Brasil (2009).

Seven mathematical models (Equation 1 to 7 ) were fitted to the experimental data of the equilibrium moisture content of ryegrass and flax seeds (Table 2).

Table 2: Mathematical models used to predict the hygroscopicity of ryegrass and flax seeds.

\begin{tabular}{|c|c|c|}
\hline Model name & Model & Equation number \\
\hline $\begin{array}{l}\text { Modified Henderson } \\
\text { (Thompson; Peart; Foster, 1968) }\end{array}$ & $X_{e}=\left[\frac{\operatorname{In}\left(1-a_{w}\right)}{-a(T+b)}\right]^{\frac{1}{c}}$ & (1) \\
\hline $\begin{array}{c}\text { Modified Halsey } \\
\text { (Iglesias; Chirife, 1976) }\end{array}$ & $X_{e}=\left[\frac{\exp (a-b T)}{-\operatorname{In}\left(a_{w}\right)}\right]^{\frac{1}{c}}$ & (2) \\
\hline $\begin{array}{c}\text { Modified Oswin } \\
\text { (Chen; Morey, 1989) }\end{array}$ & $X_{e}=(a+b T)\left[\frac{a_{w}}{1-a_{w}}\right]$ & (3) \\
\hline $\begin{array}{c}\text { Harkins-Jura } \\
\text { (Harkins, 1945) }\end{array}$ & $X_{e}=\frac{\exp (a-b T)}{c-\operatorname{In}\left(a_{w}\right)}$ & (4) \\
\hline $\begin{array}{c}\text { Copace } \\
\text { (Corrêa; Martins; Melo, 1995) }\end{array}$ & $X_{e}=\exp \left[a-(b T)+\left(c a_{w}\right)\right]$ & (5) \\
\hline $\begin{array}{c}\text { Chung Pfost } \\
\text { (Chung; Pfost, 1967) }\end{array}$ & $X_{e}=a-b \ln \left[-(T+c) \ln \left(a_{w}\right)\right]$ & (6) \\
\hline $\begin{array}{c}\text { Smith } \\
\text { (Smith, 1947) }\end{array}$ & $X_{e}=a-(b T)-c \ln \left(1-a_{w}\right)$ & (7) \\
\hline
\end{tabular}


Models were adjusted to experimental data using nonlinear regression analysis for the GaussNewton method. To select the model that best predicted the equilibrium moisture content, the determination coefficient $\left(\mathrm{R}^{2}\right)$, mean relative error (MRE), estimated standard error (SEE) and randomness of residual values were considered. The MRE and SEE values of each model were calculated using Equations 8 and 9, respectively:

$$
\begin{gathered}
\text { MRE }=\frac{100}{n} \sum_{i=1}^{n} \frac{\left|Y_{i}-\hat{Y}_{i}\right|}{Y_{i}} \\
S E E=\sqrt{\frac{\sum_{i=1}^{n}\left(Y_{i}-\hat{Y}_{i}\right)^{2}}{G L R}}
\end{gathered}
$$

where MRE is the mean relative error, \%; SEE is the estimated standard error, $\% \mathrm{db}$; $\mathrm{Y}_{\mathrm{i}}$ is the observed value, $\% \mathrm{db} ; \hat{\mathrm{Y}}$ is the estimated value by the model, $\% \mathrm{db} ; \mathrm{n}$ is the number of observed data; and DF is the residual degrees of freedom (number of observed data minus number of model parameters).

The Akaike Information Criterion (AIC) and Schwarz's Bayesian Information Criterion (BIC) were also used as statistical evaluators of the best model to predict the equilibrium moisture content of the ryegrass and flax seeds. AIC (Equation 10) is an evaluator that uses more complex selection, as verisimilitude is a qualitative character. BIC (Equation 11) is similar to AIC in terms of verisimilitude, but it presents different penalties regarding the number of estimated parameters (Burnham; Anderson, 2004). Lower values of both parameters indicate a better fit of the model (Akaike, 1974; Schwarz, 1978).

$A I C=-2 \log L+2 p$

$B I C=-2 \log L+p \ln (N-r)$

where $\mathrm{p}$ is the number of parameters in the model; $\mathrm{N}$ is the total number of observations; $r$ is the rank of the matrix $X$ (incidence matrix of fixed effects); and $\mathrm{L}$ is the maximum likelihood.

\section{RESULTS AND DISCUSSION}

Tables 3 and 4 present the parameters of the mathematical models fitted to the hygroscopic equilibrium experimental data of ryegrass and flax seeds, respectively, obtained by desorption. Furthermore, the coefficient of determination $\left(\mathrm{R}^{2}\right)$, mean relative error (MRE), estimated standard error (SEE), AIC, BIC and residual plot values are also presented.

Analysis of Tables 3 and 4 reveals that all mathematical models presented coefficient of determination $\left(\mathrm{R}^{2}\right)$ values that were higher than $96 \%$ for both products. According to Sheskin (2004), $\mathrm{R}^{2}$ defines the model success, as it evaluates the experimental data variation. However, this statistical parameter is not a reliable decision-making tool for nonlinear models, being an indicative index of the best model (Botelho et al., 2019). A model adequately represents experimental data when the MRE is less than $10 \%$ (Costa et al., 2015) and when SEE values are lower (Draper; Smith, 1998).

MRE indicates the percentage of the average error present in the model, corresponding to the model's estimated curve. Concerning the desorption isotherms of ryegrass seeds (Table 3), the Modified Halsey, Copace and Smith models are inadequate to represent the experimental data (MRE $>10 \%$ ), whereas the Smith model is the only model that fulfills this criterion for the desorption of flax seeds (Table 4).

Remaining statistical parameters must be considered to determine the proper model. SEE indicates the average error of the model and lower values indicate a greater ability by the model to describe a physical process (Draper; Smith, 1998), in the present study, the desorption process. Table 3 shows that the Chung Pfost model presented the lowest SEE values, whereas in Table 4, the Smith model had the lowest magnitudes of this parameter.

AIC and BIC were determined using other statistical parameters that selected the best model for predicting the equilibrium moisture content of the seeds. According to Ferreira Junior et al. (2018), the best model may be more precise as the criteria consider other factors such as the parametrization degree of the models compared. Considering the lowest values of AIC and BIC, the Chung Pfost model exhibited the best fit to the experimental data for the hygroscopic equilibrium of ryegrass seeds. However, for the equilibrium moisture content of flax seeds, the Smith model best fit the data. 
Table 3: Model parameters fitted to the equilibrium moisture content of ryegrass seeds, obtained by desorption, with analyzed statistical parameters.

\begin{tabular}{|c|c|c|c|c|c|c|c|}
\hline Model & Parameters $^{*}$ & $\mathrm{R}^{2}(\%)$ & SEE (decimal) & MRE (\%) & $\mathrm{AIC}$ & $\mathrm{BIC}$ & Residual plot \\
\hline Modified Henderson & $\begin{array}{l}a=0.00016 \\
b=27.30824 \\
c=1.83349\end{array}$ & 99.16 & 0.75 & 6.80 & 52.00 & 56.18 & Random \\
\hline Modified Halsey & $\begin{array}{l}a=4.843509 \\
b=0.020076 \\
c=2.007359\end{array}$ & 98.09 & 1.13 & 13.69 & 69.32 & 73.50 & Biased \\
\hline Modified Oswin & $\begin{array}{l}a=13.77001 \\
b=-0.10935 \\
c=2.71318\end{array}$ & 99.17 & 0.74 & 8.18 & 51.77 & 55.95 & Biased \\
\hline Harkins-Jura & $\begin{array}{l}a=2.8752 \\
b=0.0108 \\
c=0.5232\end{array}$ & 99.15 & 0.75 & 7.57 & 52.28 & 56.46 & Biased \\
\hline Copace & $\begin{array}{l}a=1.771080 \\
b=0.010648 \\
c=1.753426\end{array}$ & 98.68 & 0.94 & 10.67 & 61.54 & 65.72 & Biased \\
\hline Chung Pfost & $\begin{array}{l}a=31.98376 \\
b=5.90103 \\
c=22.81437\end{array}$ & 99.34 & 0.66 & 5.67 & 46.97 & 51.15 & Random \\
\hline Smith & $\begin{array}{l}a=7.666143 \\
b=0.116596 \\
c=8.671001\end{array}$ & 98.34 & 0.99 & 11.45 & 59.78 & 63.96 & Biased \\
\hline
\end{tabular}

* Significant at $1 \%$ probability according to a t-test.

Table 4: Model parameters fitted to the equilibrium moisture content of flax seeds, obtained by desorption, with analyzed statistical parameters.

\begin{tabular}{|c|c|c|c|c|c|c|c|}
\hline Model & Parameters* & $\mathrm{R}^{2}(\%)$ & SEE (decimal) & MRE (\%) & $\mathrm{AIC}$ & $\mathrm{BIC}$ & Residual plot \\
\hline Modified Henderson & $\begin{array}{l}a=0.00080 \\
b=21.95261 \\
c=1.64004\end{array}$ & 98.34 & 0.64 & 13.28 & 45.77 & 49.95 & Biased \\
\hline Modified Halsey & $\begin{array}{l}a=3.4734 \\
b=0.0244 \\
c=1.8821\end{array}$ & 96.74 & 0.90 & 21.60 & 59.81 & 63.98 & Biased \\
\hline Modified Oswin & $\begin{array}{l}a=7.774562 \\
b=-0.074514 \\
c=2.510142\end{array}$ & 98.01 & 0.70 & 15.30 & 49.54 & 53.72 & Biased \\
\hline Harkins-Jura & $\begin{array}{l}a=2.238718 \\
b=0.013650 \\
c=0.435856\end{array}$ & 98.49 & 0.61 & 14.25 & 43.75 & 47.93 & Biased \\
\hline Copace & $\begin{array}{l}a=1.121089 \\
b=0.013445 \\
c=1.925965\end{array}$ & 98.31 & 0.65 & 15.60 & 46.16 & 50.34 & Biased \\
\hline Chung Pfost & $\begin{array}{l}a=17.64801 \\
b=3.49790 \\
c=14.48074\end{array}$ & 99.05 & 0.49 & 12.53 & 43.97 & 48.15 & Biased \\
\hline Smith & $\begin{aligned} a & =4.353000 \\
b & =0.084726 \\
c & =5.149479\end{aligned}$ & 98.96 & 0.51 & 9.41 & 35.92 & 40.10 & Random \\
\hline
\end{tabular}

* Significant at $1 \%$ probability according to a t-test. 
Furthermore, analysis of the residual plot is required to verify if the model is capable of describing the phenomenon under study. A random residual plot must have residual values near the horizontal zone and should not form geometric figures (Zeymer et al., 2019). Examples of the analysis of the residual plots are presented in Figures 1 and 2.

The Modified Halsey (Figure 1A) and Modified Oswin (Figure 2A) models present a biased distribution of the residues, exhibiting defined geometric figures. In contrast, the Chung Pfost (Figure 1B) and Smith (Figure 2B) models obtained randomness residues, with positive and negative values distributed near the horizontal line, which makes them suitable for predicting the equilibrium moisture content of ryegrass and flax seeds.

Finally, Figure 3 presents an adequate correlation between the estimated and observed values of the equilibrium moisture content of ryegrass and flax seeds, respectively. Thus, the Chung Pfost and Smith models were selected to represent the desorption isotherms of ryegrass and flax seeds, respectively.

Different models often represent the sorption process of different products, such as ryegrass and flax seeds. This trend is explained by a product's physical characteristics and chemical composition. Regarding the products in the present study, ryegrass seeds are rich in starch and sugar (hydrophilic) and flax seed is rich in oil (hydrophobic).

In accordance with the present research, the Chung Pfost model has been used to represent the sorption phenomena of starchy products, such as okra seeds (Goneli et al., 2010), sweet sorghum seeds (Ullmann et al., 2016), sugar beet seeds (Corrêa et al., 2016), and rice grains (Zeymer et al., 2019). In contrast, the Smith model has
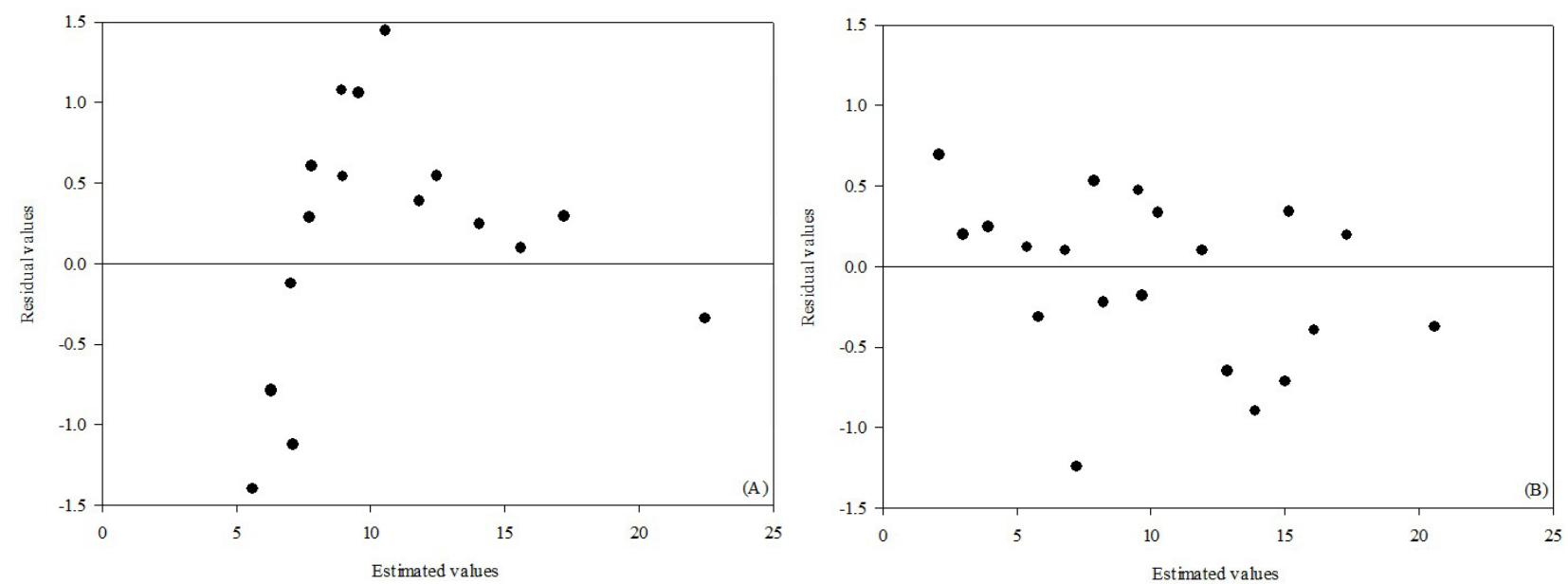

Figure 1: Residual plots of Modified Halsey (A) and Chung Pfost (B) models fit to the desorption data of ryegrass seeds.
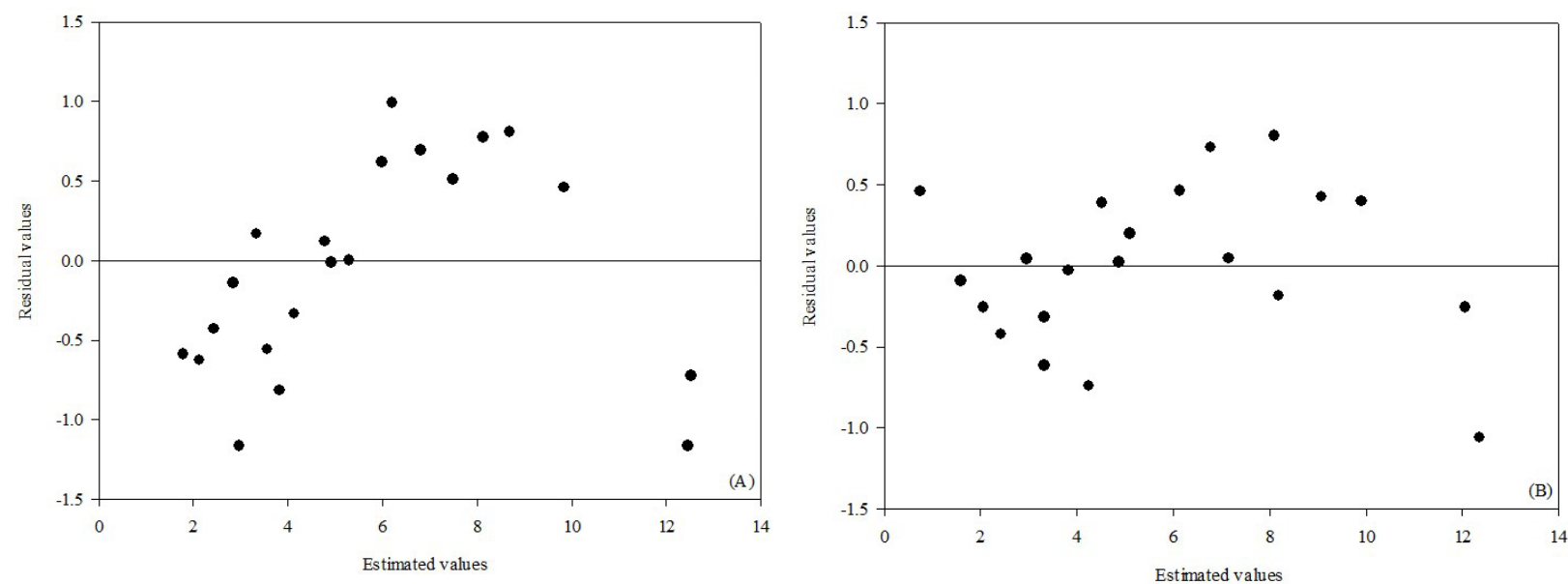

Figure 2: Residual plots of Modified Oswin (A) and Smith (B) models fit to the desorption data of flax seeds. 
been used to satisfactorily represent the hygroscopicity of oilseeds, such as jatropha seeds (Ramos; Mancini; Mendes, 2014) and sunflower seeds (Campos et al., 2019).

Figure 4 presents the experimental results of the equilibrium moisture content of ryegrass and flax seeds obtained by desorption, along with the isotherms determined by the selected models.

Figure 4 confirms the temperature influence over the desorption isotherms of ryegrass and flax seeds. At a constant water activity, the equilibrium moisture content diminishes with increasing temperatures, a trend that is reported for most agricultural products (Goneli et al., 2010; Corrêa et al., 2016; Goneli et al., 2018; Botelho et
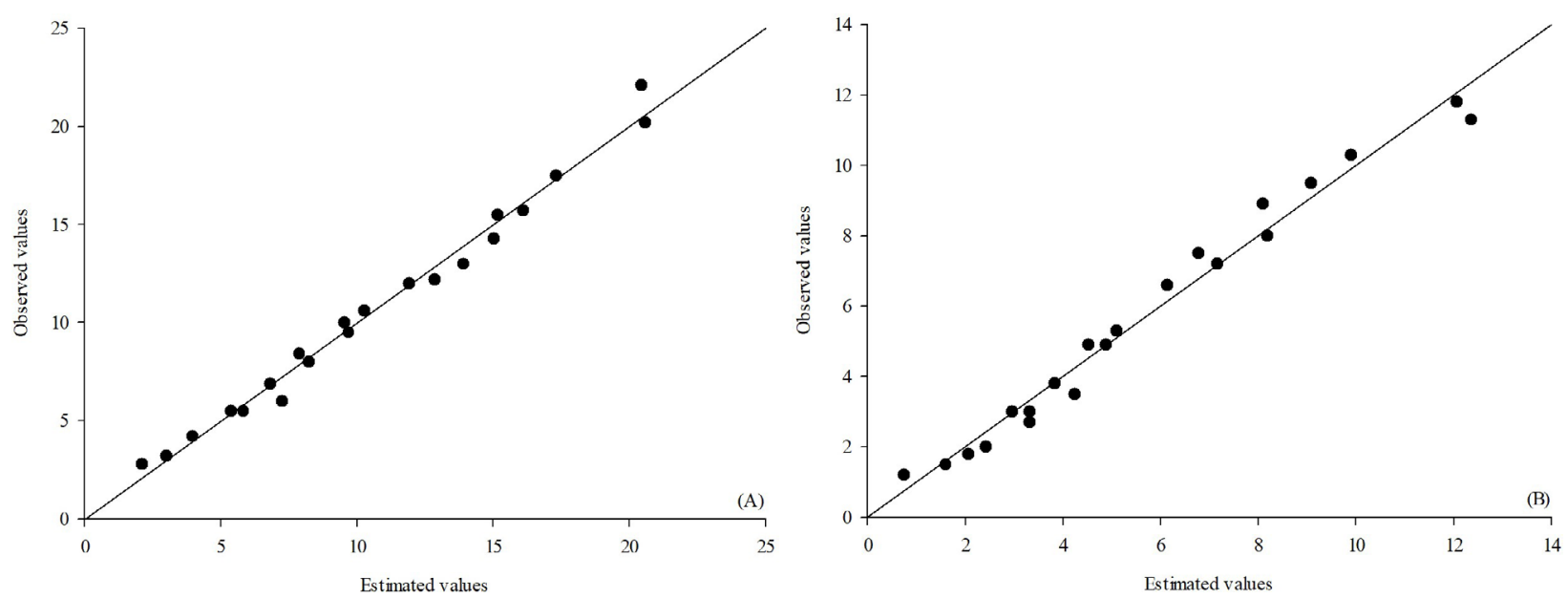

Figure 3: Chung Pfost model (A) and Smith model (B) adjusted to the experimental values for the desorption of ryegrass and flax seeds, respectively.
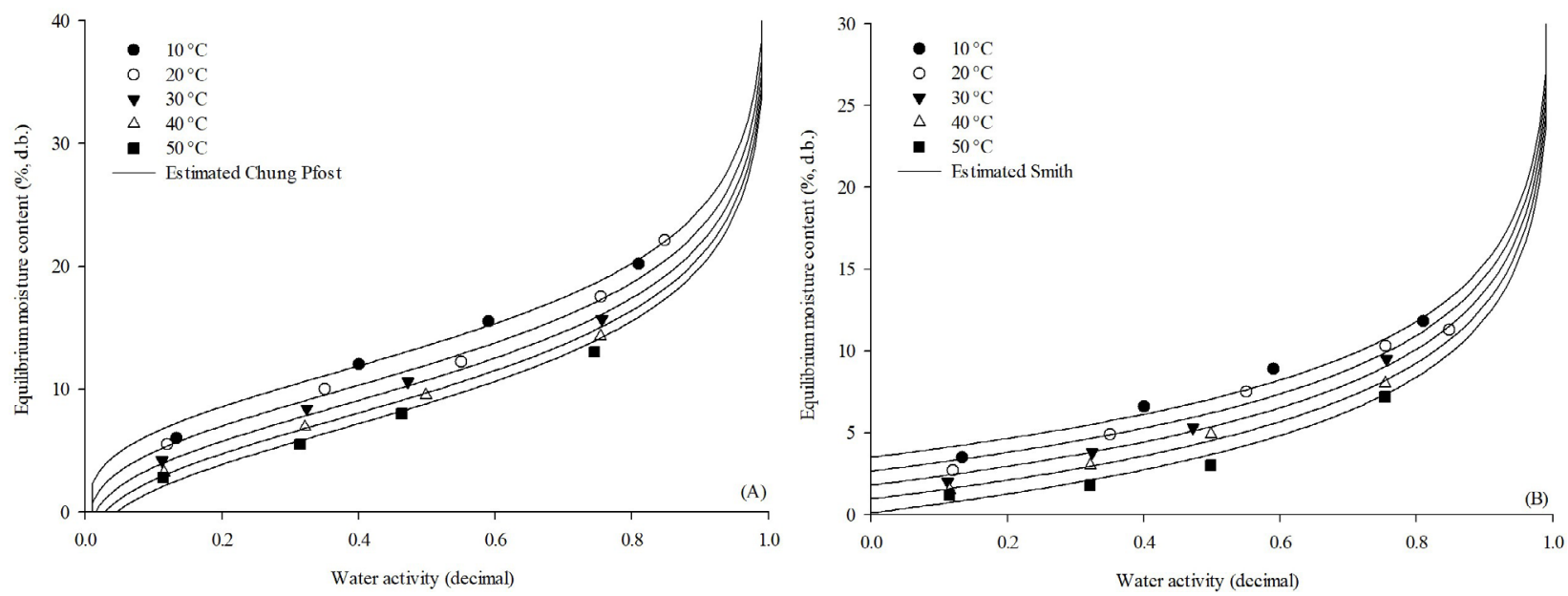

Figure 4: Observed and estimated values, based on the Chung Pfost model (A) and Smith model (B), of the equilibrium moisture content of ryegrass and flax seeds, respectively, obtained by desorption. 


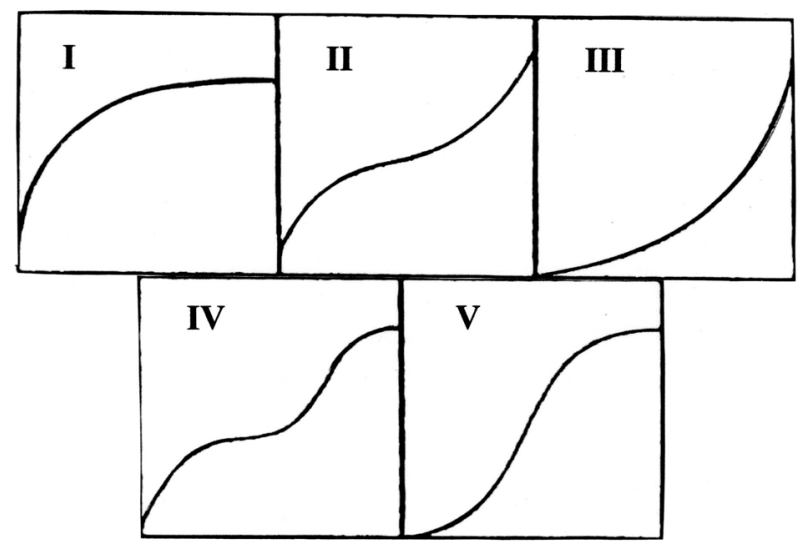

Figure 5: Brunauer classification of isotherm types. Source: Adapted from Brunauer et al. (1940).

Desorption isotherms of ryegrass seeds (Figure 4A) exhibited a sigmoidal shape, characteristic of a type II curve, among Brunauer's five forms of sorption isotherms (Figure 5). Labuza and Altunakar (2007) reported that the shape of type II isotherms is caused by synergistic effects of Raoult's law, in which capillary effects and moisture interactions occur at the material surface. Additionally, Torres and Seijo (2016) indicated that type II isotherms are typically achieved with aggregates of plate-like particles, for example, the material possess nonrigid slitshaped pores. Several studies verified the same pattern in starchy products (Tran et al., 2015; Velázquez-Gutiérrez et al., 2015; Torres; Seijo, 2016; Gili et al., 2017), such as ryegrass seeds.

However, desorption isotherms of flax seeds (Figure 4B) exhibited characteristics of a type III curve (Figure 5). According to Labuza and Altunakar (2007), the type III isotherms, known as the Flory-Huggins isotherms, are characteristic of food products that are primarily composed of components that permit the passage of light, due to a regular tridimensional arrangement of their molecules. Moisture gain, in these cases, is as low as 0.8 of $\mathrm{a}_{\mathrm{w}}$. According to Costa, Resende and Oliveira (2013), products that present type III isotherms indicate less of an affinity for water molecules, such as flax seeds, which have a high oil content.

\section{CONCLUSIONS}

The equilibrium moisture content of flax and ryegrass seeds decreases as temperature increases at a constant value of water activity. Desorption isotherms of ryegrass seeds (Type II) and flax seeds (Type III) are different, according to Brunauer's classification, due to each products' composition (starch and oil content). Based on statistical parameters, the Chung Pfost model best fit the experimental data of ryegrass seeds, whereas the Smith model best fit that of flax seeds. This difference is also due to each products' composition (starch and oil content).

\section{ACKNOWLEDGEMENTS}

The authors would like to thank the Coordenação de Aperfeiçoamento Pessoal de Nível Superior - CAPES (Coordination for the Improvement of Higher Education Personnel) for the essential support and financial aid (Finance Code 001) and the Conselho Nacional de Desenvolvimento Científico e Tecnológico - CNPq (National Council for Scientific and Technological Development) for funding the $\mathrm{PhD}$ scholarship (Process 140414/2020-7).

\section{REFERENCES}

AKAIKE, H. A new look at the statistical model identification. IEEE Transactions Automatic Control, 19(6):716-723, 1974.

ANASTASIU, A. E. de et al. Oil productivity of seven Romanian linseed varieties as affected by weather conditions. Industrial Crops and Products, 86:219-230, 2016.

ARAUJO, M. E. V. de et al. Physiological and sanitary quality of castor oil plant seeds due to ultraviolet-C radiation. Industrial Crops and Products, 137:9-15, 2019.

BASU, S.; SHIVHARE, U. S.; MUJUMDAR, A. S. Models for sorption isotherms for foods: A review. Drying Technology, 24(8):917-930, 2006.

BOTELHO, F. M. de et al. Sorption isotherms of Brazil nuts. Revista Brasileira de Engenharia Agrícola e Ambiental, 23(10):776-781, 2019.

BRASIL, Ministério da Agricultura e Reforma Agrária. Secretaria Nacional de Defesa Agropecuária. Regras para análise de sementes, Brasília, 2009. 388p.

BROOKER, D. B.; BAKKER-ARKEMA, F. W.; HALL, C. W. Drying and storage of grains and oilseeds. The AVI Publishing Company, Westport, Connecticut, USA, 1992. 450p.

BRUNAUER, S. de et al. On a theory of the van der Waals adsorption of gases. Journal of the American Chemical Society, 62(7):1723-1732, 1940.

BURNHAM, K. P.; ANDERSON, D. R. Multimodel inference: Understanding AIC and BIC in model selection. Sociological methods \& research, 33(2):261-304, 2004. 
CAMPOS, R. C. Moisture sorption isotherms of sunflower seeds: Thermodynamic analysis. Ciência e Agrotecnologia, 43:e011619, 2019

CHEN, C. C.; MOREY, V. Comparison of four EMC/ERH equations. Transactions of ASAE, 32(3):983-990, 1989.

CHUNG, D. S.; PFOST, H. B. Adsorption and desorption of water vapors by cereal grains and their products Part II. Transactions of the ASAE, 10(4):549-551, 1967.

CLOUTIER, S. de et al. SSR-based linkage map of flax (Linum usitatissimum L.) and mapping of QTLs underlying fatty acid composition traits. Molecular Breeding, 28(4):437-451, 2011.

CORRÊA, P. C.; MARTINS, D. S. R.; MELO, E. C. Umigrãos: Programa para o cálculo do teor de umidade de equilíbrio para os principais produtos agrícolas. Viçosa: Centreinar - UFV, 1995. 10p.

CORRÊA, P. C. de et al. Isotermas de dessorção de sementes de beterraba. Engenharia na Agricultura, 24(1):15-21, 2016.

CORRÊA, P. C. de et al. Moisture desorption isotherms of cucumber seeds: Modeling and thermodynamic properties. Journal of Seed Science, 37(3):218-225, 2015.

COSTA, J. M. G. de et al. Physical and thermal stability of spraydried swiss cheese bioaroma powder. Drying Technology, 33(3):346-354, 2015.

COSTA, L. M.; RESENDE, O.; OLIVEIRA, D. E. C. Isotermas de dessorção e calor isostérico dos frutos de crambe. Revista Brasileira de Engenharia Agrícola e Ambiental, 17(4):412-418, 2013.

DHINGRA, O. D.; SINCLAIR, J. B. Basic plant pathology methods. 2.ed. Boca Raton, CRC Press, 1995. 434p.

DRAPER, N. R.; SMITH, H. Applied regression analysis. New York: John Wiley \& Sons, 3 ed., 1998. 712p.

FERREIRA JUNIOR, W. N. de et al. Isotherms and isosteric heat desorption of Hymenaea stigonocarpa Mart. Seeds. Journal of Agricultural Science, 10(10):504-512, 2018.

FINCH-SAVAGE, W. E.; BASSEL, G. W. Seed vigour and crop establishment: Extending performance beyond adaptation. Journal of Experimental Botany, 67(3): 567-591, 2016

GILI, R. D. de et al. Physical characterization and fluidization design parameters of wheat germ. Journal of Food Engineering, 212:29-37, 2017.

GONELI, A. L. D. de et al. Water desorption and thermodynamic properties of okra seeds. Transactions of the ASABE, 53(1):191-197, 2010.
GONELI, A. L. D. de et al. Moisture sorption isotherms of castor beans. Part 1: Mathematical modeling and hysteresis. Revista Brasileira de Engenharia Agrícola e Ambiental, 20(8):751-756, 2018.

HARKINS, W. D. A general theory of the reaction loci in emulsion polymerization. Journal of Chemical Physics, 13(9):381382, 1945.

IGLESIAS, H. A.; CHIRIFE, J. Prediction of the effect of temperature on water sorption isotherms of food materials. Journal of Food Technology, 11(2):109-116, 1976.

LABUZA, T. P.; ALTUNAKAR, B. Water Activity Prediction and Moisture Sorption Isotherms. In: BARBOSA-CÁNOVAS, G. V. et al. (eds). Water activity in foods: Fundamentals and applications. Ames, Blackwell Publishing Professional, 2007, p.109-154.

MARCHESAN, R. de et al. Valor nutricional de cultivares de azevém consorciados ou não com aveia sob dois resíduos de pastejo. Revista de Ciências Agroveterinárias, 14(3):254-263, 2015.

MCLAUGHLIN, C. P.; MAGEE, T. R. A. The determination of sorption isotherm and the isosteric heats of sorption for potatoes. Journal of Food Engineering, 35(3):267-280, 1998.

MONTE, M. L. de et al. Moisture sorption isotherms of chitosan-glycerol films: Thermodynamic properties and microstructure. Food Bioscience, 22:170-177, 2018.

OH, S.; LEE, E. J.; HONG, G. P. Quality characteristics and moisture sorption isotherm of three varieties of dried sweet potato manufactured by hot air semi-drying followed by hot-pressing. LWT- Food Science and Technology, 94:73-78, 2018.

RAMOS, B. A.; MANCINI, M. C.; MENDES, M. F. Estudo das isotermas de equilíbrio das sementes do pinhão-manso (Vatrophas curcas L.). Revista Brasileira de Tecnologia Agroindustrial, 8(2):1385-1398, 2014.

SCHWARZ, G. Estimating the dimension of a model. The Annals of Statistics, 6(2):461-464, 1978.

SKONIESKI, F. R. de et al. Composição botânica e estrutural e valor nutricional de pastagens de azevém consorciadas. Revista Brasileira de Zootecnia, 40(3):550556, 2011.

SHESKIN, D. Handbook of parametric and nonparametric statistical procedures. CRC Press, Boca Raton, 3 ed., 2004. 406p. 
SMITH, S. E. The sorption of water vapor by high polymers. Journal of American Chemical Society, 69(3):646-651, 1947.

SORMOLI, M. E.; LANGRISH, T. A. G. Moisture sorption isotherms and net isosteric heat of sorption for spraydried pure orange juice powder. LWT - Food Science and Technology, 62(1):875-882, 2015.

TEMPLE, S. J.; VAN BOXTEL, A. J. B. Equilibrium moisture content of tea. Journal of Agricultural Engineering Research, 74(1):83-89, 1999.

THOMPSON, T. L.; PEART, R. M.; FOSTER, G. H. Mathematical simulation of corn drying - A new model. Transactions of ASAE, 11(4):582-586, 1968.

TORRES, M. D.; SEIJO, J. Water sorption behaviour of byproducts from the rice industry. Industrial Crops and Products, 86:273-278, 2016.
TRAN, P. L. de et al. Physicochemical properties of native and partially gelatinized high-amylose jackfruit (Artocarpus heterophyllus Lam.) seed starch. LWT - Food Science and Technology, 62(2):1091-1098, 2015.

ULLMANN, R. de et al. Higroscopicidade das sementes de sorgo sacarino. Revista Engenharia Agrícola, 36(3):515524, 2016.

VELÁZQUEZ-GUTIÉRREZ, S. K. de et al. Sorption isotherms, thermodynamic properties and glass transition temperature of mucilage extracted from chia seeds (Salvia hispanica L.). Carbohydrate Polymers, 121:411-419, 2015.

ZEYMER, J. S. de et al. Mathematical modeling and hysteresis of sorption isotherms for paddy rice grains. Engenharia Agrícola, 39(4):524-532, 2019.

ZUK, M. de et al. Linseed, the multipurpose plant. Industrial Crops and Products, 75:165-177, 2015. 